\title{
Social Forestry: The Balance between Welfare and Ecological Justice
}

\author{
Erina Pane*, Adam M. Yanis and Is Susanto
}

\begin{abstract}
Faculty of Sharia, Raden Intan State Islamic University Lampung, Indonesia; Postgraduate Law Student, University of Indonesia, Indonesia
\end{abstract}

\begin{abstract}
Poverty and climate change mitigation are connected to each other, so one of the policies adopted by the Indonesian government is managing forests with social forestry schemes. Where social forestry aims at prospering the poor and preserve forests. A balance between the two is needed because it is not only part of forest land, but it also considers justice for the community to get prosperous rights and realize ecological justice. The dynamics of social forestry in Indonesia are characterized by policies and regulations, but in various regions, people have succeeded in increasing their welfare while making forests sustainable. It was concluded that social forestry builds ecological strategic values that guarantee the sustainability of forest functions managed by the community. It can succeed if policies and regulations in Indonesia provide legal certainty over the rights to community-managed forest land.
\end{abstract}

Keywords: Social forest, welfare, justice.

\section{A. INTRODUCTION}

The forest functions to support life, affect the functioning of ecosystems, and biodiversity conservation (Martínez Pastur, et al. 2020). At present about thirty percent of the earth's land surface is still covered by forests, but a forest crisis occurs due to the significant narrowing of the forest area due to various human activities, such as land clearing for settlements or industry (Kumari et al. 2020). Forest damage with all its biophysical components due to human activities causes changes in the earth's climate through the greenhouse effect (Tegart et al., 1990), it has an impact on world food supply caused by a decrease in crop production (Rosenzweig, et al. 1994), because climate factors harm major food crop yields (Ali, et al. 2020).

The decline in world food supply is one of the poverty causes. Climate change in various parts of the world gives rise to hundreds of people to suffer from hunger. Philip Alston, an Australian legal expert, predicted that "there are dire consequences of climate change even in the best scenario. The world needs fundamental changes related to fossil fuels that are the source of man-made greenhouse effects. Although the impact of climate change on human rights has not received attention it represents a state of emergency without precedent." Therefore, every country needs to immediately make policies to decrease global warming and immediately carry out mitigation and adaptation to

*Address correspondence to this author at the Faculty of Sharia, Raden Intan State Islamic University Lampung, Indonesia. Address Jalan Endro Suratmin Sukarame, Bandar Lampung City, Lampung Province, post code 35131, Indonesia; Tel: +62 82281857275 , +62 8127955 5711;

E-mail: erinapane@radenintan.ac.id climate change. One of the policies undertaken to decline global warming is to reduce the environmental crisis through forest rehabilitation.

In Asia, the forestry crisis was identified because of forest clearing for agriculture, commercial logging, population growth, and infrastructure as well as industrial development. Since 1993, a meeting in the Genting Highlands, Malaysia, has discussed the governance of Asian forestry for sustainable development (Emmanuel, 1993). The meeting gave the view that the forest crisis in Asia must be addressed by changing new perspectives, that forests can prosper the community because forests have many benefits needed by the community. Thus, forest governance institutions must adapt to the new paradigm, where communities are included in forest management.

Several Asian countries have developed forestry governance schemes that involve communities. Forest management that implicates the community is known as community forestry or social forestry. The basic question is why do people need to be involved in forest management? Communities that live in and around forests are communities that are directly affected by burning forests or forests that are damaged by exploitation. Therefore, people around the forest need to be incorporated, with the aim of synergizing efforts to decrease poverty in the communities around the forest and preserve the forest. Efforts are made in rural areas, combining conservation with economic development and cultural values to benefit residents (Thomas Brendler, 1998). Forests that inserted communities are formally one solution to overcome economic and environmental problems. Community participation in managing forests is believed to be able 
to change the standard of living of the community while maintaining the ecological function of the forest.

In Nepal, 11 community forests have a positive effect on forest resources that had previously lost forest cover by almost 75 percent. Although community forest management remains a problem of forest boundary conflicts, injustice due to the low participation of poor households in decision making, and the prevalence of 'passive' forest management (Nagendra 2003). In the hilly regions of Nepal in 29 administrative districts, community forestry was developed with a productive local forest management system built on local traditions and practices for the management of forest resources (Arnold 2009). In South China, the policy of using forest land for marginal agriculture maximizes forest cover while simultaneously increasing livelihoods and reducing climate change (Tong, et al., 2020).

Forest governance involving communities is also carried out outside of Asia. In Canada, the United States, Mexico, and Bolivia promising community forests are a viable approach to forest conservation and community development (Susan, 2007). Community forestry in North America is understood as a contemporary trend in the management of stateowned protected areas and forests (James, 2005) or community forestry as a participatory forestry reform process (Jens, 2015). Community forest governance intends to decline poverty in rural areas, increase reforestation and potentially offset carbon emissions, but there are inhibiting factors to achieve this goal (Jack Baynesa, 2015).

In Indonesia, the change in forest management paradigm is manifested in social forestry governance. The Ministry of Environment provides the understanding that "social forestry is a system of sustainable forest management implemented in state forest areas or customary forests / customary forests implemented by local communities to improve their welfare, environmental balance, and socio-cultural dynamics." In the 2015-2019 period, 12.7 million hectares are allocated for social forestry. Forms of social forestry can be done through village forest schemes, community forests, community plantations, customary forests, and forestry partnerships (Menlhk, 2019), with the achievement of social forestry permits in 2017-2019 with a total land area of 4,232,855 hectares are (Geoportal Menlhk, 2019).

The formation of social forestry has a philosophy, that the existence of communities around and in the forest will be prosperous if they are involved in forest management. In practice, overlapping policies and regulations occur, giving rise to conflicts. Social forestry policy has the potential for conflict. It is caused due to different perspectives on efforts to manage forests that are inside or outside the forest area. Historical facts show that there are differences in the management of forest areas located in Java and outside Java, which include aspects of the scarcity of forest resources, claims of customary rights, and differences in the interests of the actors managing these forests (Slamet, 2009).

Whereas research located in the provinces of Lampung, Maluku, and Kalimantan, Indonesia, found that the legal consequences of the continuation of social forest management are forest tenure reforms to determine the certainty of people's rights to manage forest resources (Firdaus, 2018). Research in East Java shows that social forestry policies are very important to realize equity and development based on social justice for all Indonesian people, although there are still some problems that need to be fixed (Tasya, 2019).

Pendulum analysis predicts several forms of conflict in the future, including existing tenure conflicts being changed and transformed. Land distribution and management of partnership arrangements can also be a possible source of conflict in the future (Fatimah et al., 2019). There are obstacles to exercising forest tenure rights by communities around forests in Indonesia (Banjade, 2015). Even problems arising from the administration of tenure forest areas have led to disputes over trade interests with the control and management of forests by stakeholders in each region (Sulistiyono, 2019).

Social forestry is a link between community welfare and forest sustainability. This paper explores to examine the dynamics of the implementation of social forestry in Indonesia that can be a trigger for conflict in the future and as a comparison to examine the success of social forestry in several regions in Indonesia that can realize justice for people around the forest while maintaining ecological justice.

\section{B. RESEARCH METHODS}

This research is library research that was begun by tracking, finding, and inventorying aspects of historical development, policies, and regulations regarding forest management in Indonesia. It focused on secondary 
data obtained from literature studies, articles, and Indonesian government policies, as well as conducting a study of legal products related to social forestry in Indonesia. Data were analyzed using a policy analysis or content analysis method (Yin, 2008). The substance is analyzed regarding the dynamics of the implementation of social forestry in Indonesia.

\section{DISCUSSION}

The Dynamics of Social Forestry in Indonesia: Policy and Regulation

Indonesia allocates around 63 percent of its land area as a forest area. While the remaining land area is in the form of the non-forest area known as other use areas. Forest area is divided into three functions, namely: production forest, conservation forest, and protected forest. Production forests covering 68.8 million hectares are (57 percent of the forest area), conservation forests covering 22.1 million hectares are (18 percent of forest areas with additional water conservation areas) and protection forests serve to protect watersheds of 29.7 million hectares are (25 percent of the forest area) (KLHK, 2018). The Indonesian constitution guarantees the society to get benefits from the natural resources contained in Indonesian soil. Forests are natural wealth. With a land area of the forest area of 120,599,794.73 hectares (KLHK Statistics, 2020) the benefits of its management for the welfare of the Indonesian people should be considered.

Most Indonesian people still have economic expect from the potential of forest areas. A total of 25,800 villages, or $34.1 \%$ of the total 74,954 villages throughout Indonesia are areas directly adjacent to forest areas. The terrestrial conservation area covering 22.1 million hectares is surrounded by 6,381 villages, most of the population depend on natural resources to meet their daily needs. In the 2015-2019 period, the natural resource and ecosystem conservation program set a target of granting access to traditional uses for 100,000 hectares of the traditional zone of the national park area. Traditional zones in national park areas are designed to fulfill the necessity or depend on surrounding communities (traditionally) on available natural resources, especially non-timber forest products, associated forest products, and certain other resources. Through conservation partnerships, this moment the granting of access has contributed to 4,812 households in 62 villages in and around 15 national parks (KLHK, 2018).
To parse current forest management, the history of it in Indonesia is relevant to be studied, so that a comprehensive understanding of forest management development that has economic, ecological, and sociocultural implications (Poffenberger, 1990) can be obtained. Forest management policies in Indonesia have been going on since the Dutch era (I Nyoman, 2005; Ani, 2008; Subandi, 2009)

The Indonesian Constitution drafted in 1945 has provided an ideal principle in the management of natural resources. The state controls the earth and water and the natural resources contained in the land of Indonesia and they are used as much as possible for the prosperity of the people. The efforts of the New Order government to improve the economy were carried out by exploiting forests to obtain large foreign exchange. Forest exploitation requires capital that is legalized by the entry of foreign and domestic investors through regulation in 1967 . The regulation regulates broader state authority so that a state-based forest management law product is drafted. State-based forest management. Forest resource management is dominated by actors who have access to determining policies.

The applied legal instruments are laden with prioritizing the role and power of government which tends to neglect and freezes access and rights of local communities over forest resources (I Nyoman, 2005). Local people who have been there and have been managing forests are marginalized and impoverished.

Forest exploitation is widely undertaken in Sumatra, Kalimantan, Sulawesi, Maluku, and Irian Jaya. Forest management is carried out by foreign capital owners and domestic capital owners in the form of PrivateOwned Enterprises and State-Owned Enterprises with a concession mechanism. The concession mechanism contributes positively to the improvement of Indonesia's economic growth, but forest management concession policies are performed in a closed, non-selective manner, with weak supervision and weak law enforcement, so that exploitation of forest resources is uncontrolled (I Nyoman, 2005). The result is a degradation in the quantity and quality of tropical forests in various regions in Indonesia. Local people who have lived for generations from the forest lost their sources of life and neglected their rights to forest resources (I Nyoman, 2005; Subadi, 2009).

Uncontrolled exploitation of forests results in a forest crisis. Since the late 1990s, various rehabilitation 
initiatives have been put through. Forest rehabilitation is executed by developing large-scale industrial plantations, to meet the increasing demand for wood for the rapidly growing needs of the timber and paper industry, while rehabilitating critical land (Ani et al., 2008). Forest rehabilitation ends with a change in Indonesian politics. The right of the entrepreneur was terminated to manage the forest but left the vast critical forest due to logging.

During the reform period, the rehabilitation paradigm gave rise to the response that forest rehabilitation must provide certainty to the people who live in and around the forest to get its benefits and the people involved in forest and land rehabilitation activities. The process executes ignoring the sociocultural aspects. Indicators of neglect of this aspect are that there is no recognition of local community organizations as partners (Ani et al., 2008). The role of adat institutions is not taken into account. The right to manage the rehabilitated area is given half, especially in the forest area. Communities have the right to manage with formal requirements, a memorandum of understanding is developed that is strengthened by local regulations, where the community manages an area together with the district forestry service. Meanwhile, land managed under a cooperation agreement is prepared by cooperatives or other farmer groups based on customary territorial boundaries

The responsiveness of forestry regulations began in early 2000, through the regulation of Law No. 41 of 1999 whereby the implementation of forestry must be followed out based on benefits and sustainability. Forestry operations must pay attention to a balanced and preservation of environmental, social, and cultural balance. 2001) provides an understanding that there is recognition of the law if it gives maximum benefit to the community. Rolling up to 2016, the issuance of Regulation of the Minister of Environment and Forestry of the Republic of Indonesia Number 83 of 2016 concerning Social Forestry.Following the 2015-2019 National Medium-Term Development Plan, 12.7 million hectares of forest land are allocated to be accessed by the community through the Social Forestry program. Until October 2018, the total area of Indonesia had reached 2.2 million hectares from various forms of Social Forestry. The Social Forestry Program was developed through granting funds to the public in the form of revolving credit (recipients of People's Business Credit) whose allocation in 2017 amounted to Rp. 95.5 trillion or equivalent to USD 7 million). The assistance is used to increase community access to capital and markets to achieve economic autonomy, the social forestry program has contributed 6.3 percent to farmers' income.

Social forestry policy is undergoing the development of regulations, whereby social forestry is adjusted to Law Number 23 of 2014 concerning Regional Government. Therefore, adjustments to social forestry policies are needed with local government regulations. Through the Minister of Environment and Forestry Regulation Number P.83 of 2016 concerning Social Forestry, the policy has not directly answered the problems in the field as a result of the issuance of the Regional Government Law. In the Ministerial Regulation, it is determined that there is a requirement that "local governments must have a social forestry program and provide a budget to implement it." there are policy revisions that should be adjusted to local government regulations (Christine, 2016).

In 2019, the development of social forestry policy will be part of President Joko Widodo's agrarian reform policy. The politics of agrarian development under the Jokowi Government is based on agrarian conditions in Indonesia which are on a critical threshold. The level of welfare of the community, especially farmers is low, is not balanced with land ownership. This is due to "indecisive policies in handling agrarian issues, such as strict rules on land tenure and uneven land redistribution. Not a bit of criticism and even resistance by the community against this policy by assessing the agrarian reform policy is not a solution of the agrarian conditions that are on the verge of being critical" (Sianturi, 2018). In total, this policy allocates 21.7 million hectares of land to farmers. In detail, 9 million hectares are through redistribution and legalization through certificates under the Ministry of Agrarian Affairs and Spatial Planning. A total of 12.7 million acres are under the supervision of social forestry outside Java and 1,127,073 hectares are social forestry in Java.

Until now the conflict occurred when the community felt that the social forestry policy launched from the outset was considered to be not in line with expectations. There is no legal certainty to manage forest land around their settlements. There is discrimination among farmers in the use of forest land promised by the government. Farmers find it difficult to process permits to manage land (Dwi Reka, 2019). The problem that still occurs is the implementation of social forestry programs in the field out of sync between the Ministry of Environment and Forestry with the 
Indonesian State Forest Company (Bayu, 2019). Distribution of social forestry land to the beneficiary community has not been executed optimally. In 2020, based on the Indonesian Center for Environmental Law's notes on the forestry sector, it was explained that the simplification of various omnibus laws in the draft work copyright law would have an impact on Indonesia's forests (Lusia, 2020). Forest problems in general will affect the implementation of social forestry in Indonesia.

\section{Manifesting a Balance between Welfare and Ecological Justice}

The dynamics of social forestry in Indonesia reveal overlapping policies and regulations, but some regions can show that the implementation of social forestry can create a balance between welfare and ecological justice. Some examples include the implementation of social forestry in Bantaeng Regency, South Sulawesi, Dusun Kalibiru, Yogyakarta Special Region, Tebing Tinggi Timur District, Riau, and Pasaman Regency, West Sumatra.

The position of the forest in the view of the Indonesian people is based on the forest as a source of livelihood. The community directly feels the benefits of non-timber forest products, such as rattan, honey, fruits, and ornamental plants. Communities also feel the benefits of indirect value or the value of forest environmental services, such as water. Water has a very large indirect economic value, apart from being a source of clean water, water irrigates rice fields, and can be managed to produce electricity through microhydro. This makes clear the economic value of forests can encourage economic development at the local level.

In Indonesia, for a long time, the community managed the forest, but the management was implemented without having the legality of formal rights so that it was considered as a forest encroacher because of regulations that prohibited the activity in the forest area. Local communities have a very limited understanding of social forestry which has several schemes that can provide opportunities to obtain formal legal rights to manage forest areas. Supratman argues that "people lose information about their rights, roles, and responsibilities in managing forests because communication between public service institutions and forest communities is not connected" (Supratman et al., 2013). Some of the descriptions below illustrate how social forestry can benefit the community while preserving the forests
Social forestry can take the form of village forest schemes. Village forest in Bantaeng Regency, South Sulawesi Province is one of the pioneers. The governor gives the community the legitimacy of forest management rights. Institutional transformation occurs in which the strengthening of local forest management institutions becomes formal village forest management institutions in the form of Village-Owned Enterprises. In its implementation, it was agreed on a set of rules and behavior. These rules include: "every farmer is prohibited from changing the status and function of the village forest area, prohibited from cutting down trees, prohibited from burning shrubs or grass to clear his land and or for land expansion." Violations committed are given sanctions that cause forest managers to lose their rights.

Before there was village forest management, the level of community welfare was still relatively low. Economic indicators show that "each household is only able to meet their living needs on average by 73.6 percent of their ideal needs. After securing village forest management rights, the community developed coffee plants organically, developed beekeeping, planted passion fruit trees, used rattan." Development carried out with an agroforestry pattern has the potential to increase farmers' production and income two to three times the current production without disrupting the protected function of the forest area. Furthermore, the community manages commercial water from the river through water installations that have been built since 1988. This is a consequence of granted forest management rights through protecting the forest areas that serve as river areas in which they take water. Supratman argues that "there are consequences of the obligation to protect river catchment areas is the number of costs that must be incurred for carrying out such protection activities. building institutional systems so that water user communities can provide compensation to fund forest protection activities. The river has also been cultivated by the community as an energy source for microhydropower plants"(Supratman et al., 2013).

Kalibiru Hamlet of the Special Region of Yogyakarta has been administered to manage social forestry in a community forestry scheme. The people of Kalibiru Hamlet can manage community-based forests so that economic, social, and ecological interests are integrated. In 1999 it was the first pilot of an ecotourism area, with temporary permits from community forests turning critical forest areas into productive. The ecotourism area that was formed has provided 
economic advantages and it can improve the lives of the surrounding community. Activities in the ecotourism area take the form of agricultural activities and making crafts, food, and others. This economic activity is directly beneficial to grow and increase people's income. The prosperity that has been obtained, controlling the desire of the community to cut wood in the forest. The success of the Kalibiru Hamlet in social forestry is due to the policy being rolled out that places the community as subjects who have knowledge and experience in managing forest resources sustainably (Suhardi, 2017).

Since 2007, an area of 10,390 hectares of land covering seven villages in Tebingtinggi Timur, Riau Archipelago Meranti is still in the Industrial Plantation Forest concession scheme of PT. Lestari Unggul Makmur. At the end of 2008, PT. Lestari Unggul Makmur operates the construction of canals for the benefit of land clearing and includes acacia seedlings. Since the canalization was accomplished, the surrounding land, especially community land, began to dry up and fires started. The peak occurred in 2014 which consumed more than 2,400 hectares of community land. The results of the Global Forest Watch analysis of forest fires in the Riau region show that fires on peatlands last longer, generate more smoke, and peat fires are more difficult to extinguish (Nigel et al., 2014). Forest fires that occur have an impact on the level of public health and forest damage. After President Joko Widodo's visit, PT. Lestari Unggul Makmurdan handed over the management of the forests of seven villages under the village forest scheme. Through Presidential Regulation No.88 of 2017, changes were made to the boundaries of the forest area, so that the community could manage the forest with a village forest scheme. The community actively participates in managing the village forest. (M. Nasir et al., 2018). Furthermore, to anticipate the destruction of village forests, the use, and management of timber is regulated through village regulations and monitored by village business entities. Arranged a ban on village forest logging, and was given a written warning and forestry criminal reporting (Paragraph, 2017).

In 2012-2017, West Sumatra Pasaman District was stipulated in a community-managed forest scheme. The target of expanding the area of community managed forest area of 500,000 hectares, of which 71,000 hectares are charged to Pasaman Regency as a form of forestry development in the region. In 2015, Pasaman Regency was only able to realize it, covering an area of 1,366 hectares. The low percentage of achievements in the expansion of community-managed forest areas is due to the lengthy and prolonged licensing process and stages, low human resource capacity (officials and forest farmer groups), inadequate financial support, unclear village boundaries, and overlapping social forestry areas with other licensing. The people of Pasaman Regency develop social forestry by efforts to formulate alternative strategies and policy directions for the development of social forestry in Pasaman Regency. There are nine main strategies prioritized, one of which is "increasing the role of government and community participation in improving the economy and the quality of human resources through the development of knowledge systems, technology transfer and forestry education" (Muhdian, 2017).

\section{CLOSING}

Social forestry with various community-based forest management schemes is a link between community welfare and forest sustainability. In Indonesia, the expansion of social forestry, experiences various obstacles, partly due to differences in forest management principles between several parties. The dynamics of social forestry management is characterized by overlapping policies and regulations. It requires synchronization of policies and regulations regarding ownership of rights to managed forest land. Clear status of land ownership will reduce conflict because the community gets a guarantee for the managed forest land. Management of social forestry must actively involve the community. The management community must be organized. Formed local organizations can be a link for communities for knowledge gaps in sustainable forest management.

\section{REFERENCES}

Ali, $S$ et al., Does technical progress mitigate climate effect on crops yield in Pakistan?, Volume 30, Issue 3, June 2020, Pages 663-676, Publisher: Pakistan Agricultural Scientists Forum. https://doi.org/10.36899/JAPS.2020.3.0079

Ani Adiwinata Nawir , op.cit, hlm. 17

Ani Adiwinata Nawir, Murniati, Lukas Rumboko, Tinjauan Rehabilitasi Hutan Pelajaran dari Masa Lalu Akan kemanakah arahnya setelah lebih dari tiga dasawarsa?, Center for International Forestry Research, retrived https://www.cifor.org/ publications/pdf_files/Books/BNawir0801Ina.pdf?q=hutan\#pa ge $=57$

Arnold, J.E. Michael; Campbell, J. Gabriel, Collective Management of Hill Forests in Nepal: The Community Forestry Development Project, 2009, Indiana University, URI:http://hdl.handle.net/10535/8112

Ayat S Karokaro, Kala Desa-desa di Riau Ini Peroleh Hak Kelola Hutan, 3 April 2017 https://www.mongabay.co.id/ 
2017/04/03/kala-desa-desa-di-riau-ini-peroleh-hak-kelolahutan/

Banjade, M.R, Herawati, T, Liswanti, N, Mwangi, E. Constraints to exercising forest tenure rights by forest adjacent communities in Indonesia, 2015

Bayu Prasetyo, Presiden bahas hambatan perhutanan sosial saat terima wakil petani Kamis, 10 Oktober 2019 12:57 WIB, https://www.antaranews.com/berita/1105536/presidenbahas-hambatan-perhutanan-sosial-saat-terima-wakil-petani

Christine Wulandari, Pitojo Budiono, Dodik Ridho Nurrochmat, Kesiapan Daerah dalam Implementasi Program Perhutanan Sosial Pasca Terbitnya UU 23/2014 tentang Pemerintahan Daerah, Jurnal Risalah Kebijakan Pertanian dan Lingkungan, IPB University, Bogor, Volume 3, Nomor 2, Agustus 2016, hlm. 108-116. https://doi.org/10.20957/jkebijakan.v3i2.15512

Direktorat Penyiapan Kawasan Perhutanan Sosial, Direktorat Jenderal Perhutanan Sosial dan Kemitraan Lingkungan, Kementerian Lingkungan Hidup dan Kehutanan Indonesia, http://pkps.menlhk.go.id/

Direktorat Penyiapan Kawasan Perhutanan Sosial, Direktorat Jenderal Perhutanan Sosial dan Kemitraan Lingkungan, Kementerian Lingkungan Hidup dan Kehutanan Indonesia, http://geoportal.menlhk.go.id/arcgis/apps/webappviewer/inde x.html?id=004299e9f8f24d2d9aca1365904d18ed

Dwi Reka Barokah, Demo Petani, Kebijakan Perhutanan Sosial Tak Sesuai Harapan, Gatra.com, tanggal 10 Oktober 2019 jam 15:10 WIB, retrived https://www.gatra.com/detail/ news/450067/politik/demo-petani-kebijakan-perhutanansosial-tak-sesuai-harapan

Emmanuel D' Silva, S. Appanah and Malaysia Forestry Research Institute. Forestry Management for Sustainable Development, Published: September 1993, ISBN: 978-08213-2597-1 https://doi.org/10.1596/0-8213-2597-3

Fatimah, A.H.P.dan Sahide, M.A.K.,What conflicts possible: A new social forestry partnership policy in a National Park in Indonesia, IOP Conference Series: Earth and Environmental ScienceVolume 343, Issue 1, 6 November 2019, Article number 012050 1st International Conference of Interdisciplinary Research on Green Environmental Approach for Sustainable Development, ICROEST 2019, Universitas Muhammadiyah Buton Makassar, Indonesia 3 August 2019 through 4 August 2019, Publisher: Institute of Physics Publishing https://doi.org/10.1088/1755-1315/343/1/012050

Firdaus, AY, Panduan Praktis Penerapan Kebijakan Perhutanan Sosial, Publiser: Center for International Forestry Research (CIFOR), 2018, ISBN 978-602-387-075-2 https://doi.org/10.17528/cifor/006856

I Nyoman Nurjaya, op.cit

I Nyoman Nurjaya, Sejarah Hukum Pengelolaan Hutan di Indoensia, Jurnal Jurisprudence, Volume 2, Nomor 1, Maret 2005, hlm. $51-52$

ibid

Jack Baynesa et al., Key factors which influence the success of community forestry in developing countries, Global Environmental Change, Volume 35, November 2015, Pages 226-238. https://doi.org/10.1016/..gloenvcha.2015.09.011

James McCarthy, Devolution in the Woods: Community Forestry as Hybrid Neoliberalism, Environment and Planning A 2005, Volume 37, pages 995-1014, First Published June 1, 2005 Research Article. https://doi.org/10.1068/a36266

Jens Friis Lund, Paradoxes of participation: The logic of professionalization inparticipatory forestry, Forest Policy and Economics journal. https://doi.org/10.1016/j.forpol.2015.07.0091389-9341
Kementerian Lingkungan Hidup dan Kehutanan 2018, op.cit hlm. xxviii

Kementerian Lingkungan Hidup dan Kehutanan 2018, Status Hutan dan Kehutanan di Indonesia, Penerbit Kementerian Lingkungan Hidup dan Kehutanan Republik Indonesia, 2019, ISBN: 978-602-8358-85-9

Kumari, B., Pandey, A.C., Kumar, A. Remote Sensing approach to evaluate anthropogenic influences on Forest Cover of Palamau Tiger Reserve, Eastern India Ecological, Volume 9, Issue 1, 1 December 2020, Article number 17, pp 1-11, Publisher: Springer https://doi.org/10.1186/s13717-020-0219-z

Lusia Arumingtyas, Nasib Suram Hutan Negeri, Ada Omnibus Law, Makin Buram, Jakarta, 21 March 2020 https://www.mongabay.co.id/2020/03/21/nasib-suram-hutannegeri-ada-omnibus-law-makin-buram/

M. Nazir Salim, Sukmo Pinuji, Westi Utami,Reforma Agraria di Kawasan Hutan Sungaitohor, Riau: Pengelolaan Perhutanan Sosial di Wilayah Perbatasan, Bhumi: Jurnal Agraria dan Pertanahan Volume 4, Nomor 2, 2018 https://doi.org/10.31292/jb.v4i2.277

Martínez Pastur, G.J et al., Ecological perspectives on variable retention forestry, Ecological Processes, Volume 9, Issue 1, 1 December 2020, Article number 12, pp 2-6, Publisher: Springer https://doi.org/10.1186/s13717-020-0215-3

Muhdian, Prasetya Darmawan, Strategi Pengembangan Perhutanan Sosial Sumatera Barat (Studi Kasus Kabupaten Pasaman). Masters thesis, Universitas Andalas. 2017, URI: http://scholar.unand.ac.id/id/eprint/25560

Nagendra Prasad Yadav, et al., Forest Management and Utilization Under CommunityForestry, Journal of Forest and Livelihood 3(1) July, 2003, pp 37-50

Nigel Sizer Nigel Sizer, Andrew Leach, Susan Minnemeyer, Mark Higgins, Fred Stolle, James Anderson and Julius Lawalata, Mencegah Kebakaran Hutan Di Indonesia: Fokus Pada Provinsi Riau, Lahan Gambut, Serta Pembakaran Ilegal, 11 Juni 2014, retrived https://www.wri.org/blog/2014/06/ mencegah-kebakaran-hutan-di-indonesia-fokus-padaprovinsi-riau-lahan-gambut-serta

Pemberian konsesi eksploitasi sumber daya hutan berdasarkan Peraturan Pemerintah No. 21 Tahun 1970 junto Peraturan Pemerintah No. 18 Tahun 1975 tentang Hak Pengusahaan Hutan dan Hak Pemungutan Hasil Hutan.

Poffenberger, Mark, "Introduction", dalam Mark Poffenberger (Ed), Keepers of The Forest, Land Management Alternatives in Southeast Asia, Ateneo de Manila University Press, 1990, pp. 3-5.

Rasdjidi, L., \& Rasdjidi, I, Dasar-DasarFilsafat dan TeoriHukum. Bandung, Citra Aditya Bakti, 2001

Rosenzweig, C., Parry, M.L., Potential impact of climate change on world food supply Volume 367, Issue 6459, 1994, Pages 133-138.

https://doi.org/10.1038/367133a0

Sianturi, Rida Evri Yani Politik Pembangunan Agraria Rejim JokowiJusuf Kalla (Kebijakan Tanah Objek Reforma Agraria dan Perhutanan Sosial), 2018, Repositori Institusi Universitas Sumatera Utara , retrived http://repositori.usu.ac.id/handle/ 123456789/4179

Slamet Edi Sumanto, Kebijakan Pengembangan Perhutaanan Sosial dalam Perspektif Resolusi Konflik (Social Forestry Development Policy in Conflict Resolution Perspective), Jurnal Analisis Kebijakan Kehutanan, Volume 6, Nomor 1, April 2009, hlm. 13 - 25

Statistik Kementerian Lingkungan Hidup dan Kehutanan 2018 Catatan: Luas kawasan hutan per fungsi didasarkan/mencuplik pada lembar SK kawasan hutan yang diterbitkan oleh Menteri Lingkungan Hidup dan Kehutanan, update terakhir : 17 Februari 2020, https://www.bps.go.id/ statictable/2013/12/31/1716/luas-kawasan-hutan 
Subadi, Tiga Setengah Abad Pengelolaan Tanah Kawasan Hutan Jawa (Pendekatan Sejarah dan Politik Hukum Pada Masa Kolonial), Jurnal Sosial, Volume 10 Nomor 1, Maret 2009, hlm. 10

Suhardi Suryadi, Direktur LP3ES 2005-2010 dan Konsultan Knowlegde Management Proyek Lestari-Usaid, Dilema Perhutanan Sosial, $16 \quad$ Okober 2017, http://pskl.menlhk.go.id/kliping/191-dilema-perhutanansosial.html

Sulistiyono, A., Handayani, G.A.K.R., The conflict resolution on tenurial forest areas in Indonesia-based economic justice (Article), International Journal of Advanced Science and Technology, Volume 28, Issue 20, 31 December 2019, Pages 391-398, Publisher: Science and Engineering Research Support Society

Supratman, Muhammad Alif K. Sahide, Hutan Desa dan PembangunanSosial Ekonomi Masyarakat Desadi Kabupaten Bantaeng, Kerjasama:Kementerian Kehutanan, dan Kemitraan. Jakarta, 2013, hlm. 28, retrived https://core.ac.uk/reader/77627860

Susan Charnley, Melissa R. Poe, Community Forestry in Theory and Practice: Where Are We Now? Annual Review of Anthropology, Volume 36, pages 301-336 (Volume publication date 21 October 2007) https://doi.org/10.1146/annurev.anthro.35.081705.123143
Tasya Moedy Agusti, I Nyoman Nurjaya, Imam Kuswahyono, Implementasi Regulasi Perhutanan Sosial yang Berkemanfaatan bagi Masyarakat Sekitar Hutan, Jurnal IImu Pendidikan dan Kewarganegaran, Jurnal IImiah Pendidikan Pancasila dan Kewarganegaraan, Volume 4, Nomor 2, 2019, hlm. 300-309 https://doi.org/10.17977/um019v4i2p300-309

Tegart, W. J. McG., Sheldon, G. W. \& Griffiths, D.C. Intergovernmental Panel on Climate Change, Climate Change: The IPCC Impacts Assessment, Aust. Govt Publishing Serv., Canberra, 1990

Thomas Brendler, Henry Carey, Community Forestry, Defined, Journal of Forestry, Volume 96, Issue 3, March 1998, Pages 21-23, https://doi.org/10.1093/jof/96.3.21

Tong, X. et al., Forest management in southern China generates short term extensive carbon sequestration, Volume 11, Issue 1, 1 December 2020, Article number 129, pp 1-10, Publisher: Nature Research

https://doi.org/10.1038/s41467-019-13798-8

Yin, R.K. Studi Kasus Design dan Metode. Jakarta: PT Raja Grafindo Perkasa. 2008

Received on 12-11-2020

Accepted on 15-12-2020

Published on 18-01-2021

DOI: https://doi.org/10.6000/1929-4409.2021.10.10

(C) 2021 Pane et al.; Licensee Lifescience Global.

This is an open access article licensed under the terms of the Creative Commons Attribution Non-Commercial License (http://creativecommons.org/licenses/by-nc/3.0/) which permits unrestricted, non-commercial use, distribution and reproduction in any medium, provided the work is properly cited. 